\title{
(C) OPEN ACCESS \\ MRI of malignant peripheral nerve sheath tumour in pericardial cavity
}

\author{
Ryoma Endo, ${ }^{1}$ Tomoko Tomioka, ${ }^{1}$ Ken Okada, ${ }^{2}$ Kanichi Inoue ${ }^{1}$
}

${ }^{1}$ Cardiology, Southmiyagi

Medical Center, Miyagi, Japan

${ }^{2}$ Radiology, Southmiyagi

Medical Center, Miyagi, Japan

\section{Correspondence to} Dr Tomoko Tomioka, tomoko.t@southmiyagi-mc.jp

RE and TT contributed equally.

Accepted 18 April 2018

\section{DESCRIPTION}

Malignant peripheral nerve sheath tumour (MPNST) is a rare phenotype of soft tissue sarcoma which accounts for $\sim 2 \%$ of all sarcomas. ${ }^{1}$ It is said to be highly possible to cause recurrence and metastasis, therefore early diagnosis is important.

This report shows an MRI of MPNST in a pericardial cavity which has not been reported yet. The patient was a 30-year-old woman with a history of ulcerative colitis. She visited our hospital because of chest discomfort during inspiration and running a fever of $38^{\circ} \mathrm{C}$. Transthoracic echocardiography demonstrated a mass beside the left atrium in the pericardial cavity with a lot of pericardial effusion. Since further information was needed to identify the true character of the mass immediately, we next performed a contrast-enhanced CT. It showed heterogeneously enhanced image of the mass in the pericardial cavity; however, we could not define whether the mass was a tumour or an abscess (figure 1). For further investigation, we performed an MRI and found the striking images best with Fast Imaging Employing Steady-state Acquisition (FIESTA) (figure 2). The FIESTA image of the mass, approximately $55 \mathrm{~mm}$ in major axis in the pericardial cavity, was heterogeneous which was constructed of a mixture of parenchyma and cyst. The mass was in contiguity with both left atrium and left ventricle; however, no invasion to the parietal and visceral pericardium, even to myocardium was found. The pericardium was thickened with a lot of pericardial effusion. From the above-mentioned FIESTA findings, the large tumour size, the heterogeneity of the tumour, the presence of intratumoral cystic lesions, the pericardial

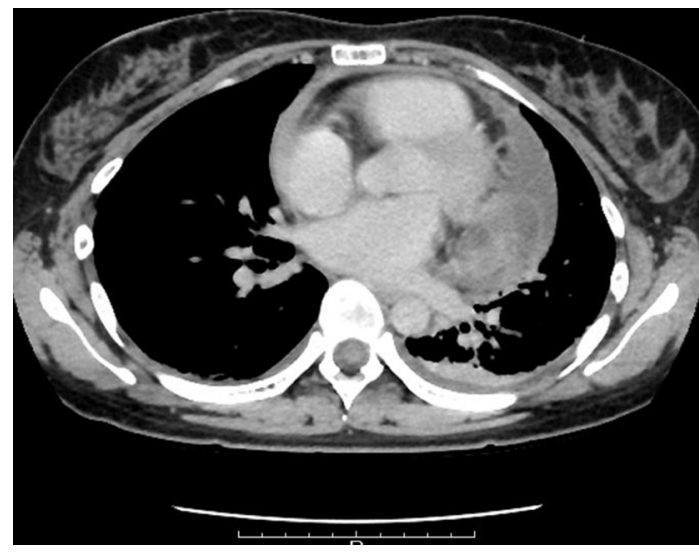

Figure 1 Axial CT shows a heterogeneous mass localised in the pericardial cavity.



Figure 2 FIESTA MRI shows a large heterogeneous mass which is constructed of a mixture of parenchyma and cyst in the pericardial cavity and shows pericardial thickness with a large amount of pericardial effusion.

thickness with a large amount of pericardial effusion and the enhanced signal intensity (image not shown), we strongly suggested that the mass was a malignant tumour (ie, a sarcoma), ${ }^{2} 3$ and not a benign tumour or abscess, although positron emission tomography or cytology of pericardial effusion showed no malignant findings. Then, a thoracotomy was performed for a definite diagnosis. The tumour was originated from peripheral nerve of peripulmonary artery, and tumour itself was destructed in the pericardial cavity. Moreover, intraoperative frozen section was with malignant cells, therefore an extensive resection was performed under a cardiopulmonary bypass. The final pathological diagnosis was MPNST. Since we were concerned about metastasis, postoperative chemotherapy was given for 6 months, and no recurrence has been found as of today, that is 1 year after tumour resection.

Definite diagnosis of MPNST is difficult by means of non-invasive modality only; however, MRI may

Learning points

- Malignant peripheral nerve sheath tumour could be found in the pericardial cavity as in this case.

- MRI will give us a better suggestion than CT on the diagnosis of malignant peripheral nerve sheath tumour. 
lead us to predict whether the mass is a malignant tumour and lead us to decide whether to perform early surgical intervention as in this case. MPNST is said to be with poor prognosis, so it is very important to pay attention whenever we find such a large heterogeneous mass at any region with MRI for early therapeutic intervention.

Contributors RE, TT, KO and KI equally contributed to the diagnosis and to the decision-making of the early surgical intervention on this patient. RE wrote this manuscript and TT also contributed to the writing of this manuscript as a supervisor.

Funding This work was carried out with the budget of the Southmiyagi Medical Center

Patient consent Obtained.

Ethics approval Only patient consent was required by our affiliation

Provenance and peer review Not commissioned; externally peer reviewed.
Open Access This is an Open Access article distributed in accordance with the Creative Commons Attribution Non Commercial (CC BY-NC 4.0) license, which permits others to distribute, remix, adapt, build upon this work non-commercially, and license their derivative works on different terms, provided the original work is properly cited and the use is non-commercial. See: http://creativecommons.org/ licenses/by-nc/4.0/

(C) BMJ Publishing Group Ltd (unless otherwise stated in the text of the article) 2018. All rights reserved. No commercial use is permitted unless otherwise expressly granted.

\section{REFERENCES}

1 Farid M, Demicco EG, Garcia R, et al. Malignant peripheral nerve sheath tumors. Oncologist 2014;19:193-201.

2 Kakkar C, Shetty CM, Koteshwara P, et al. Telltale signs of peripheral neurogenic tumors on magnetic resonance imaging. Indian J Radiol Imaging 2015;25:453-8.

3 Wasa J, Nishida Y, Tsukushi S, et al. MRI features in the differentiation of malignant peripheral nerve sheath tumors and neurofibromas. AJR Am J Roentgenol 2010;194:1568-74.

Copyright 2018 BMJ Publishing Group. All rights reserved. For permission to reuse any of this content visit

http://group.bmj.com/group/rights-licensing/permissions.

BMJ Case Report Fellows may re-use this article for personal use and teaching without any further permission.

Become a Fellow of BMJ Case Reports today and you can:

- Submit as many cases as you like

- Enjoy fast sympathetic peer review and rapid publication of accepted articles

Access all the published articles

Re-use any of the published material for personal use and teaching without further permission

For information on Institutional Fellowships contact consortiasales@bmjgroup.com

Visit casereports.bmj.com for more articles like this and to become a Fellow 